\title{
Influence of Different Levels of Coconut Shell Biochar on Nutrients Concentration and Nutrient Uptake by Soybean
}

\author{
D. S. Rohitha*, B. Mamatha, K. M. Srinivas Reddy, H. C. Prakasha and Nagappa Desai \\ Department of Soil Science and Agricultural Chemistry, College of Agriculture, University of \\ Agricultural Sciences, Bangalore, Karnataka, India \\ *Corresponding author
}

\section{A B S T R A C T}

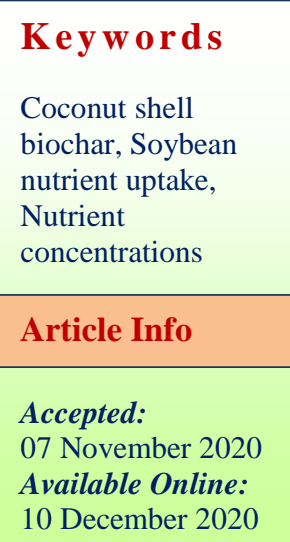

\section{Keywords}

Coconut shell biochar, Soybean Nutrient concentrations

\section{Introduction}

Biochar, which is produced by the thermochemical decomposition of organic material (crop residues and wood waste) under partial or full exclusion of oxygen (pyrolysis) at a relatively higher temperature range of $450 \mathrm{C}$ to $600 \mathrm{C}$ and it has been the subject of researchers for many years. Converting inexpensive, available crop straws into biochar and adding them to soils can have substantial agricultural and environmental benefits (Wang et al., 2013). There is sufficient evidence that due to its particular structure and composition, biochar land use may theoretically increase carbon sequestration, boost soil health and crop productivity by contributing to sustainable management of organic residues (Lehmann and Joseph, 2009).

Additions of biochar to soil have shown definite increases in cation exchange capacity (CEC) and $\mathrm{pH}$. Biochar application also improves the overall sorption capacity of soils and therefore it might influence the availability, transport and fate of different nutrients in the soil. The increase in the 
availability of major plant nutrients due to application of biochar was also reported by Glaser et al., 2000 and Lehmann et al., 2003. However, very few studies have been conducted regarding the influence of biochar application on nutrient retention and their availability to crop plant. Therefore, the objective of the present study was to assess the effect of biochar application on nutrients concentration and uptake of essential nutrients by soybean.

\section{Materials and Methods}

A Field experiment was conducted in AICRP on sunflower unit, ZARS, UAS, GKVK Bangalore $\quad\left(13^{0} 04{ }^{\prime} 37.7^{\prime} \mathrm{N} \quad 77034^{\prime}\right.$ '04.2'E) during Kharif 2019 with a test crop soybean. The recommended dose of fertilizer (25:62.5:25 N, $\mathrm{P}_{2} \mathrm{O}_{5}$ and $\mathrm{K}_{2} \mathrm{O}$ ) applied as basal dose with recommended spacing of $30 * 10 \mathrm{~cm}$. Randomized complete block design was used with nine treatment and 3 replication. Table 1 provides the details of initial soil physical and chemical properties from experimental area.

There are various grades of biochar available and the locally produced coconut shell biochar has been used in the present investigation. The coconut shell biochar was developed at a comparatively higher temperature (around $600{ }^{\circ} \mathrm{C}$ ) in limited oxygen supply and it was purchased for the cost of Rs. 2 per kg from company Kalpatharu products, Tiptur, Tumkur district, Karnataka. The physical and chemical properties of coconut shell biochar are given in Table 1 and following are the treatment combinations used in the present study.

\section{Treatments details}

The experiment comprised of 9 treatments. The treatment details are: T1-Absolute control; T2-Package of Practice
(Recommended NPK + FYM; T3Recommended NPK + Biochar@5 t ha ${ }^{-1}$; T4-Recommended NPK + Biochar@ 7.5 t ha ; T5-Recommended NPK + Biochar@10 t ha $^{-1}$; T6-Package of Practice (Recommended NPK + FYM $+100 \%$ Lime Recommendation; T7-Recommended NPK + Biochar @ 5 t $\mathrm{ha}^{-1}+\quad 50 \% \quad$ Lime Recommendation; T8-Recommended NPK + Biochar @ $7.5 \quad \mathrm{t} \quad \mathrm{ha}^{-1}+\quad 50 \%$ Lime Recommendation; T9-Recommended NPK + Biochar @ $10 \mathrm{t} \quad \mathrm{ha}^{-1}+\quad 50 \% \quad$ Lime Recommendation With $\mathrm{ZnSO}_{4}-12.5 \mathrm{~kg} \mathrm{ha}^{-1}$ for all treatments except in absolute control; Farm Yard Manure $6.25 \mathrm{t} \mathrm{ha}^{-1}$; Recommended Lime $3.0 \mathrm{t} \mathrm{ha}^{-1}$; NPK Provided through Urea, Diammonium Phosphate and Muriate of potash

\section{Collection and Preparation of plant samples}

Seeds and plant samples of soybean were obtained from five separate plants randomly picked from all twenty-seven plots at the crop harvest. The samples of the shoot were washed and cut into tiny pieces, dried at $60{ }^{\circ} \mathrm{C}$ for around 10 hours and then ground using Willey stainless steel mill and preserved in polythene bags. The plant and seed samples obtained from the crop were dried powdered and examined for macronutrients $(\mathrm{N}, \mathrm{P}, \mathrm{K}$, $\mathrm{Ca}, \mathrm{Mg}$, and $\mathrm{S}$ ) and micronutrients $(\mathrm{Fe}, \mathrm{Zn}$, $\mathrm{Mn}$ and $\mathrm{Cu}$ ).

\section{Methods employed for plant and seed sample analysis of soybean}

\section{Nitrogen $(\%)$ content of soybean}

0.5 grams of plant and seeds samples were digested with conc. sulphuric acid $\left(\mathrm{H}_{2} \mathrm{SO}_{4}\right)$ and digestion mixture $\left(\mathrm{K}_{2} \mathrm{SO}_{4}: \mathrm{CuSO}_{4} .5 \mathrm{H}_{2} \mathrm{O}\right.$ : selenium in the ratio of 100:20:1) until green residue was collected. The digested content was distilled by the Micro Kjeldhal. The 
ammonia produced was trapped in boric acid $\left(\mathrm{H}_{3} \mathrm{BO}_{4}\right)$ and was then measured by titrating against standardized sulphuric acid (Piper, 1966).

\section{Digestion of plant samples for nutrients estimation}

One gram of the dried and ground samples (plant and seeds) was pre-digested with $10 \mathrm{ml}$ $\mathrm{HNO}_{3}(62 \%)$ for 24 hours, then digested in a vacuumed chamber at $85^{\circ} \mathrm{C}$ on sand bath with the following steps: the pre-digested samples were treated with $10 \mathrm{ml}$ di-acid mixture reagent $\left(\mathrm{HNO}_{3}+\mathrm{HClO}_{4}\right.$ at a ratio of 10:4) and held on sand bath until white precipitate was left in the bottom.

After filtration, the digested samples were diluted with distilled water and volume formed to a defined concentrations. Using normal techniques this extract was used to estimate $\mathrm{P}, \mathrm{K}, \mathrm{Ca}, \mathrm{Mg}$ and micronutrients $(\mathrm{Fe}$, $\mathrm{Cu}, \mathrm{Mn}$, and $\mathrm{Zn}$ ).

\section{Methods employed for nutrients estimation of soybean Plant and seeds}

Using the Diacid digested samples, The phosphorus content measurement by vanodomolybdophosphoric yellow colour method (Piper, 1966) potassium content bythe flame photometer (Piper, 1966)Calcium and Magnesium using versenate titration process Piper (1966). Sulphur was measured by using the process called turbidometry.

The turbidity intensity produced in the sample was calculated at $420 \mathrm{~nm}$ wavelength using a spectrophotometer, as outlined by Piper (1966).Micronutrients ( $\mathrm{Zn}, \mathrm{Cu}, \mathrm{Mn}$ and $\mathrm{Fe}$ ) in seeds and plants were measured by Perkin Elmer atomic absorption spectrophotometer using hallow cathode lamps and presented as $\mathrm{mg} \mathrm{kg}$ in plant and seed sample samples (Jackson 1973).

\section{Uptake of Nutrients $\left(\mathrm{kg} \mathrm{ha}^{-1}\right)$ by soybean}

The Uptake of macronutrients $(\mathrm{N}, \mathrm{P}, \mathrm{K}, \mathrm{Ca}$, $\mathrm{Mg}$ and $\mathrm{S}$ ) and micronutrients (Fe, $\mathrm{Mn}, \mathrm{Zn}$ and $\mathrm{Cu}$ ) by soybean was calculated after the analysis of nutrients concentrations in soybean leaf, stem, root and seeds. For the calculation of the uptake the concentration of each nutrient in leaf, stem, root and seeds were multiplied with their respective dry biomass. The formula below is used to measure the nutrient uptake for macro and micro nutrients.

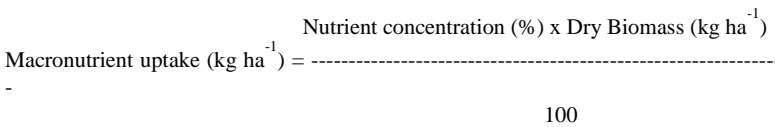

Micronutrient uptake $\left(\mathrm{g} \mathrm{ha}^{-1}\right)=\left(\begin{array}{c}\text { Nutrient concentration }\left(\mathrm{mg} \mathrm{kg}^{-1}\right) \times \text { Dry Biomass }\left(\mathrm{kg} \mathrm{ha}^{-1}\right) \\ -1000\end{array}\right.$

\section{Statistical analysis of data}

The comparative study of experimentally collected results was carried out by implementing Fisher's system of measurement of variance as described by Gomez and Gomez (1984). The significance level used in the ' $F$ ' evaluation was offered at 5 per cent. Critical difference (CD) values are presented at a significance level of 5 per cent in the table, wherever the ' $F$ ' measure was found to be relevant at 5 per cent.

\section{Results and Discussion}

\section{Effect of biochar on major nutrient concentration in soybean seeds after the harvest}

The concentration of major nutrients in seeds had a significant difference between treatments. In treatments $\mathrm{T} 9$, which received recommended NPK + Biochar @ $10 \mathrm{t} \mathrm{ha}^{-1}+$ $50 \%$ Lime Recommendation had higher nitrogen $(5.75 \%)$, phosphorus (0.54\%)and 
potassium $(1.46 \%)$ concentration when compared to $\mathrm{T} 2 \quad(5.68 \%$ nitrogen, $0.44 \%$ phosphorus and $1.40 \%$ potassium which had Package of Practice (Recommended NPK + FYM)

With the application of recommended NPK + Biochar @ $10 \mathrm{t} \quad \mathrm{ha}^{-1}+50 \% \quad$ Lime Recommendation (T9), significant increase in $\mathrm{N}, \mathrm{P}$ and $\mathrm{K}$ content in seeds was recorded. This is probably due to biochar application in combination with agricultural lime which served as the storehouse of several macro and micronutrients released during the mineralization process. In addition to releasing plant nutrients from the organic matter, the organic acids formed in the decomposition process like citric acid, tannic acid and oxalic acid also dissolve and release the native nutrients into the soil and increase the availability to plants. Lehmann et al., (2003), recorded similar result

Effect of biochar on secondary nutrient concentration in soybean seeds after the harvest

The concentration of calcium and magnesium in seed varies significantly among the treatments. But, sulphur concentration was in significant. The higher Calcium (0.84 \%) Magnesium $(0.42 \%)$ and sulphur $(0.68 \%)$ was observed in $\mathrm{T} 9$, which was provided with Recommended NPK + Biochar@ $10 \mathrm{t} \mathrm{ha}^{-1}+$ $50 \%$ Lime Recommendation when compared to T2 $(0.75 \%$ Calcium, $0.36 \%$ Magnesium and $0.66 \%$ Sulphur) which had Package of Practice (Recommended NPK + FYM).

Significant increase in $\mathrm{Ca}$ and $\mathrm{Mg}$ content in seeds was recorded. This could be due to the biochar application in combination with agricultural lime which served as a storehouse of basic cations released during the mineralization process. Dagnija et al., (2018), recorded a similar report. The improvement in sulphur is attributed to bioavailability and mineralization by biochar application.(Deluca et al., 2009) (Table 2)

Effect of biochar on micronutrients concentration in soybean seeds after the harvest

The concentration of Iron, Manganese and Copper in seeds did not vary significantly with respect to biochar application rates in combination with agricultural lime. But, the concentration of Zinc had a significance. The numerically higher content of Iron $(76.09 \mathrm{mg}$ $\mathrm{kg}^{-1}$ ), Zinc (40.11 mg kg-1), Manganese (24.63 $\mathrm{mg} \mathrm{kg}^{-1}$ ) and Copper (4.55 $\mathrm{mg} \mathrm{kg}^{-1}$ ) was found in T8 (Recommended NPK + Biochar @ 7.5 t ha $^{-1}+\quad 50 \%$ Lime Recommendation).

Slight numerical increase in concentration of $\mathrm{Fe}, \mathrm{Zn}, \mathrm{Mn}$ and $\mathrm{Cu}$ were recorded using Recommended NPK + Biochar @ $10 \mathrm{t} \mathrm{ha}^{-1}+$ 50\% Lime Recommendation (T9). This may be attributed to the biochar application in combination with agricultural lime, which contained large concentrations of these nutrients present in the biochar and in soil was released during the mineralization cycle. Biochar-related application of plant biomass actively releases organic compounds in the rhizosphere which can mobilize the micronutrients and increase their concentration in seeds reported (Antonio. et al (2013). Beesley and Marmiroli (2011) have carried out related studies that the supply of micronutrients depends on the soluble carbon contained in the biochar and $\mathrm{pH}$ level.

\section{Effect of coconut shell biochar on major nutrient concentration in soybean plant}

The concentration of major nutrients in plant had a significant difference between treatments. In treatments $\mathrm{T} 9$, which received recommended NPK + Biochar @ $10 \mathrm{t} \mathrm{ha}^{-1}+$ 
50\% Lime Recommendation had higher nitrogen $(3.96 \%)$, phosphorus (0.43\%)and potassium $(0.89 \%)$ concentration when compared to $\mathrm{T} 2 \quad(3.82 \%$ nitrogen, $0.26 \%$ phosphorus and $0.68 \%$ potassium which had Package of Practice (Recommended NPK + FYM) (Table 3).

Significant increase in $\mathrm{P}$ and $\mathrm{K}$ content in plant and numerically slight increase in $\mathrm{N}$ content was recorded with the application of Recommended NPK + Biochar @ $10 \mathrm{t} \mathrm{ha}^{-1}+$ $50 \%$ Lime Recommendation $\left(\mathrm{T}_{9}\right)$. This may be attributed to the biochar application, which acted as the storehouse of both macro and micronutrients and was released during the mineralization cycle. In addition to extracting plant nutrients from the organic matter, the organic acids produced through the cycle of decomposition often unlock the natural nutrients in the soil and improve plant supply. Lehmann et al., (2003), recorded similar results. Application of the biochar generated at a temperature of $400{ }^{\circ} \mathrm{C}$ and with a low $\mathrm{C}$ : $\mathrm{N}$ ratio leads to improved soil productivity and is expressed in further straw and grain uptake (Lehman et al., 2003). Increased assimilation of $\mathrm{N}$ that increased root growth also improved the concentration and uptake of other two major nutrients (Chamorro et al., 2002).

\section{Effect of coconut shell biochar on secondary nutrient concentration in soybean plant}

The concentration of calcium in plant varies significantly among the treatments. But, magnesium and sulphur concentration was in significant. The higher Calcium (1.18\%) Magnesium $(0.61 \%)$ and sulphur $(0.25 \%)$ was observed in $\mathrm{T} 9$, which was provided with Recommended NPK + Biochar @ $10 \mathrm{t} \mathrm{ha}^{-1}+$ 50\% Lime Recommendation when compared to $\mathrm{T} 2(0.89 \%$ Calcium, $0.40 \%$ Magnesium and $0.20 \%$ Sulphur) which had Package of
Practice (Recommended NPK + FYM).With the application of Recommended NPK + Biochar @ 10 t $\mathrm{ha}^{-1}+50 \%$ Lime Recommendation (T9), slight numerical increase in $\mathrm{Ca}$ and $\mathrm{Mg}$ content in soybean plant was noted. This could be due to the biochar application in combination with agricultural lime which served as a reservoir of basic cations released during the mineralization process. Dagnija et al., (2018) recorded similar report. Increase in $\mathrm{pH}$ of acidic soil due to biochar application that could decrease aluminium toxicity can therefore be expected to increase root growth and absorption of nutrients. Major et al., 2010 stated the similar findings. The improvement in sulphur is attributed to bioavailability and mineralization by biochar application.(Deluca et al., 2009)

\section{Effect of coconut shell biochar on Micronutrient concentration in soybean plant}

The concentration of Iron, Manganese and Copper in plant did not vary significantly with respect to biochar application rates in combination with agricultural lime. But, the concentration of Zinc had a significance. The numerically higher content of Iron $(54.63 \mathrm{mg}$ $\mathrm{kg}^{-1}$ ), Zinc (30.07 $\mathrm{mg} \mathrm{kg}{ }^{-1}$ ), Manganese (39.02 $\mathrm{mg} \mathrm{kg}^{-1}$ ) and Copper (16.49 $\mathrm{mg} \mathrm{kg}^{-1}$ ) was found in T9 (Recommended NPK + Biochar @ 10 t ha $^{-1}+50 \%$ Lime Recommendation) and the lower amount of micronutrients was found in absolute control which did not provide an additional supply of nutrients and biochar as an amendment.

Application of biochar in several experiments is associated with increasing $\mathrm{pH}$ level which dissolves the fixed micronutrients and decreases micronutrient volatility. However, the micronutrients may be mobilized in the presence of bio char accompanied by good biomass output which actively releases 
organic compounds into the rhizosphere. Soybean plant has typically found a numerically slight increase in micronutrients and decreased absorption of $\mathrm{Zn}$ and $\mathrm{Cu}$ was seen, which can be due to the antagonistic impact of other soil nutrients, hampering the supply of $\mathrm{Zn}$ and $\mathrm{Cu}$ for plant availability. (Antonio et al, 2013 and Deluca et al., 2009)

\section{Effect of coconut shell biochar on major nutrients uptake by soybean}

Total Major Nutrient's consumption across soybean was substantially different due to various biochar rates (Table 4). Significantly higher total uptake of nitrogen (196.31 $\mathrm{kg} \mathrm{ha}{ }^{-1}$ ) phosphorus (19.02 $\mathrm{kg} \mathrm{ha}^{-1}$ ) and potassium $\left(46.58 \mathrm{~kg} \mathrm{ha}^{-1}\right)$ was observed in $\mathrm{T} 9$ which received Recommended NPK + Biochar @ 10 t $\mathrm{ha}^{-1}+50 \% \quad$ Lime Recommendation followed by T5 $(191.87 \mathrm{~kg}$ $\mathrm{ha}^{-1}$ Nitrogen, $17.68 \mathrm{~kg} \mathrm{ha}^{-1}$ Phosphorus and $45.79 \mathrm{~kg} \mathrm{ha}^{-1}$ Potassium) which received Recommended NPK + Biochar @ $10 \mathrm{t} \mathrm{ha}^{-1}$. The lower uptake was recorded in absolute control which received no external source of nutrients and biochar as amendment.

The reason for higher intake of nitrogen under high doses of biochar may be due to the positive effects of biochar on crop growth, along with positive effects of crop plant uptake on nutrients $(\mathrm{P}, \mathrm{K}, \mathrm{Ca}$, and $\mathrm{Mg}$ ) and soil availability of $\mathrm{P}, \mathrm{K}, \mathrm{Ca}$, and $\mathrm{Mg}$. Increase in acidic soil $\mathrm{pH}$ can decrease $\mathrm{Al}$ development, thereby improving root growth and expected nutrient uptake. The intake of nutrients is a feature of the nutrient quality and the output of biomass. Increased biochar application rate increased the production of biomass which obviously increased the nutrient uptake.

Table.1 Initial physico-chemical properties of the soil of experimental area and coconut shell biochar

\begin{tabular}{|c|c|c|}
\hline Parameters & Soil & Coconut shell biochar \\
\hline Sand $(\%)$ & 68.83 & \\
\hline Silt (\%) & 17.86 & \\
\hline Clay (\%) & 13.29 & \\
\hline Soil textural class & Sandy loam & \\
\hline Bulk density $\left(\mathrm{Mg} \mathrm{m}^{-3}\right)$ & 1.39 & 0.73 \\
\hline Maximum water holding capacity (\%) & 34.13 & 68.54 \\
\hline Soil pH & 5.16 & 9.6 \\
\hline Electrical conductivity $\left(\mathrm{d} \mathrm{S} \mathrm{m}^{-1}\right)$ & 0.097 & 1.78 \\
\hline Organic carbon & $0.51 \%$ & $77.50 \%$ \\
\hline Nitrogen & $262.71 \mathrm{~kg} \mathrm{ha}^{-1}$ & $0.27 \%$ \\
\hline Phosphorus & $26.82 \mathrm{~kg} \mathrm{ha}^{-1}$ & $0.15 \%$ \\
\hline Potassium & $136.4 \mathrm{~kg} \mathrm{ha}^{-1}$ & $0.84 \%$ \\
\hline Exchangeable Calcium & $2.16 \mathrm{cmol}(\mathrm{p}+) \mathrm{kg}^{-1}$ & $0.22 \%$ \\
\hline Exchangeable Magnesium & $1.35 \mathrm{cmol}(\mathrm{p}+) \mathrm{kg}^{-1}$ & $0.13 \%$ \\
\hline Sulphur & $9.30 \mathrm{mg} \mathrm{kg}^{-1}$ & $0.02 \%$ \\
\hline Iron $\left(\mathrm{mg} \mathrm{kg}^{-1}\right)$ & 11.12 & 423.06 \\
\hline Zinc $\left(\mathrm{mg} \mathrm{kg}^{-1}\right)$ & 2.02 & 25.80 \\
\hline Manganese $\left(\mathrm{mg} \mathrm{kg}^{-1}\right)$ & 6.01 & 273.26 \\
\hline Copper $\left(\mathrm{mg} \mathrm{kg}^{-1}\right)$ & 0.55 & 31.20 \\
\hline
\end{tabular}


Table.2 Effect of coconut shell biochar application on concentration of major and micro nutrients in soybean seeds after the harvest

\begin{tabular}{|c|c|c|c|c|c|c|c|c|c|c|}
\hline \multirow[t]{2}{*}{ Treatments } & \multicolumn{6}{|c|}{ Major nutrients (\%) } & \multicolumn{4}{|c|}{ Micro Nutrients (mg kg $\left.{ }^{-1}\right)$} \\
\hline & Nitrogen & Phosphorus & Potassium & Calcium & Magnesium & Sulphur & Iron & Zinc & Manganese & Copper \\
\hline T1 & 5.65 & 0.43 & 1.38 & 0.74 & 0.35 & 0.64 & 75.89 & 39.37 & 23.09 & 4.00 \\
\hline $\mathbf{T} 2$ & 5.68 & 0.44 & 1.40 & 0.75 & 0.36 & 0.66 & 75.98 & 39.41 & 23.98 & 4.02 \\
\hline T3 & 5.71 & 0.47 & 1.41 & 0.75 & 0.36 & 0.67 & 75.95 & 39.45 & 23.85 & 4.16 \\
\hline $\mathbf{T 4}$ & 5.72 & 0.49 & 1.44 & 0.75 & 0.40 & 0.67 & 75.96 & 39.54 & 24.09 & 4.27 \\
\hline T5 & 5.75 & 0.53 & 1.46 & 0.77 & 0.39 & 0.68 & 76.04 & 40.01 & 24.54 & 4.32 \\
\hline T6 & 5.69 & 0.45 & 1.42 & 0.79 & 0.36 & 0.66 & 75.96 & 39.48 & 23.67 & 4.42 \\
\hline T7 & 5.72 & 0.47 & 1.43 & 0.81 & 0.37 & 0.67 & 76.06 & 40.03 & 24.55 & 4.48 \\
\hline T8 & 5.72 & 0.50 & 1.46 & 0.83 & 0.40 & 0.68 & 76.09 & 40.11 & 24.63 & 4.55 \\
\hline T9 & 5.75 & 0.54 & 1.44 & 0.84 & 0.42 & 0.68 & 76.07 & 40.06 & 24.59 & 4.51 \\
\hline SEm \pm & 0.02 & 0.01 & 0.03 & 0.05 & 0.03 & 0.01 & 0.02 & 0.03 & 0.03 & 0.02 \\
\hline CD @ 5\% & NS & NS & 0.10 & 0.14 & 0.07 & NS & NS & 0.09 & NS & NS \\
\hline
\end{tabular}

Note: $* \mathrm{ZnSO}_{4} @ 12.5 \mathrm{~kg} \mathrm{ha}^{-1}$ common for all treatments except in absolute control

Table.3 Effect of coconut shell biochar application on concentration of major and micro nutrients in soybean plants after the harvest

\begin{tabular}{|c|c|c|c|c|c|c|c|c|c|c|}
\hline \multirow[t]{2}{*}{ Treatments } & \multicolumn{6}{|c|}{ Major nutrients (\%) } & \multicolumn{4}{|c|}{ Micro Nutrients (mg kg ${ }^{-1}$ ) } \\
\hline & Nitrogen & Phosphorus & Potassium & Calcium & Magnesium & Sulphur & Iron & Zinc & Manganese & Copper \\
\hline T1 & 3.8 & 0.21 & 0.64 & 0.81 & 0.35 & 0.16 & 53.41 & 25.61 & 36.73 & 14.07 \\
\hline $\mathbf{T 2}$ & 3.82 & 0.26 & 0.68 & 0.89 & 0.40 & 0.20 & 53.7 & 25.65 & 36.79 & 14.70 \\
\hline T3 & 3.85 & 0.31 & 0.75 & 0.88 & 0.41 & 0.21 & 53.8 & 25.88 & 37.26 & 14.79 \\
\hline T4 & 3.9 & 0.37 & 0.79 & 0.93 & 0.44 & 0.24 & 54.01 & 27.71 & 37.74 & 14.98 \\
\hline T5 & 3.94 & 0.37 & 0.86 & 1.02 & 0.48 & 0.25 & 54.35 & 27.99 & 38.17 & 15.25 \\
\hline T6 & 3.84 & 0.32 & 0.75 & 1.01 & 0.49 & 0.21 & 53.84 & 25.93 & 37.36 & 14.85 \\
\hline T7 & 3.88 & 0.34 & 0.76 & 1.06 & 0.53 & 0.21 & 54.42 & 28.35 & 38.38 & 15.53 \\
\hline T8 & 3.92 & 0.37 & 0.83 & 1.12 & 0.56 & 0.24 & 54.53 & 29.03 & 38.76 & 15.85 \\
\hline T9 & 3.96 & 0.43 & 0.89 & 1.18 & 0.61 & 0.25 & 54.63 & 30.07 & 39.02 & 16.49 \\
\hline SEm \pm & 0.02 & 0.04 & 0.03 & 0.05 & 0.03 & 0.01 & 0.02 & 0.04 & 0.03 & 0.02 \\
\hline CD@ $9 \%$ & NS & 0.12 & 0.10 & 0.14 & NS & NS & NS & 0.11 & NS & NS \\
\hline
\end{tabular}

Note: $* \mathrm{ZnSO}_{4} @ 12.5 \mathrm{~kg} \mathrm{ha}^{-1}$ common for all treatments except in absolute control 
Table.4 Effect of coconut shell biochar application on total uptake of major and micro nutrients by soybean

\begin{tabular}{|c|c|c|c|c|c|c|c|c|c|c|}
\hline \multirow[t]{2}{*}{ Treatments } & \multicolumn{6}{|c|}{ Major nutrients $\left(\mathrm{kg} \mathrm{ha}^{-1}\right)$} & \multicolumn{4}{|c|}{ Micro Nutrients ( $\left.\mathrm{g} \mathrm{ha}^{-1}\right)$} \\
\hline & Nitrogen & Phosphorus & Potassium & Calcium & Magnesium & Sulphur & Iron & Zinc & Manganese & Copper \\
\hline T1 & 139.56 & 9.83 & 30.29 & 20.79 & 10.59 & 13.15 & 189.08 & 95.80 & 77.85 & 21.03 \\
\hline $\mathbf{T 2}$ & 169.33 & 12.70 & 38.01 & 25.70 & 13.25 & 17.18 & 228.46 & 116.01 & 91.02 & 23.49 \\
\hline T3 & 173.42 & 14.21 & 39.55 & 26.50 & 13.77 & 17.89 & 232.85 & 118.55 & 93.00 & 24.40 \\
\hline T4 & 183.96 & 16.04 & 43.07 & 28.12 & 15.46 & 19.27 & 246.33 & 127.46 & 98.60 & 26.56 \\
\hline T5 & 191.87 & 17.68 & 45.79 & 30.43 & 16.10 & 20.43 & 255.93 & 133.65 & 103.65 & 29.69 \\
\hline T6 & 171.43 & 13.65 & 39.47 & 28.22 & 14.13 & 17.52 & 230.89 & 117.64 & 91.73 & 24.56 \\
\hline $\mathbf{T} 7$ & 181.16 & 15.06 & 41.89 & 30.59 & 15.32 & 18.72 & 243.30 & 127.24 & 99.11 & 28.46 \\
\hline T8 & 186.78 & 16.54 & 44.56 & 32.89 & 16.90 & 19.82 & 250.73 & 131.73 & 102.47 & 29.35 \\
\hline T9 & 196.38 & 19.02 & 46.58 & 34.74 & 18.56 & 20.91 & 262.07 & 138.11 & 106.82 & 31.47 \\
\hline SEm \pm & 5.87 & 0.92 & 1.67 & 1.38 & 0.77 & 0.78 & 7.19 & 4.24 & 2.92 & 1.14 \\
\hline CD @ 5\% & 17.58 & 2.77 & 5.00 & 4.14 & 2.33 & 02.33 & 21.55 & 12.70 & 8.76 & 3.43 \\
\hline
\end{tabular}

Note: $* \mathrm{ZnSO}_{4} @ 12.5 \mathrm{~kg} \mathrm{ha}^{-1}$ common for all treatments except in absolute control 
Chan et al., (2007) and Zhao et al., (2014) noted a rise in $\mathrm{N}$ uptake at higher biochar levels. Sohi et al., (2013) and Yao et al., (2013) reported that primary nutrient bioavailability and plant uptake increased in response to biochar application, especially when combination with agricultural lime and chemical fertilizers. Deluca et al., (2009) stated that biochar added with an organic $\mathrm{N}$ source to the soil yielded an increase in net nitrification and improved plant availability of nitrogen.

The addition of biochar in combination of agricultural lime neutralized the soil $\mathrm{pH}$, thereby releasing the fixed $\mathrm{Fe}-\mathrm{P}$ and $\mathrm{Al}-\mathrm{P}$ increased the available phosphorus. This is in line with the reports of Milla et al., (2013). Aziz et al., (2006) indicated that the increased availability of $\mathrm{P}$ can also be induced healthy root development by reduced Al toxicity which causes root damage. Similarly, with the introduction of biochar, Uzoma et al., (2011) and Yamato et al., (2006) recorded an improvement of the available plant $\mathrm{P}$ in soil. The increase in $\mathrm{K}$ concentration and uptake may be due to biochar ash content which helps to release occluded mineral nutrients such as $\mathrm{K}$ for crop use immediately. Most of the uptake of nutrients ( $\mathrm{N}$ and $\mathrm{K})$ will increase as the biochar influences the increased availability of water. In addition, biochar has the capacity to increase the soil's $\mathrm{CEC}$, thereby increasing soil's ability to hold $\mathrm{K}$ and make it available for plant uptake. The availability of $\mathrm{K}$ increased as the soil $\mathrm{pH}$ increased by applying biochar in combination with agricultural lime Eazhilkrishna et al., 2017also reported increased K uptake by common bean plant biomass.

Effect of coconut shell biochar on secondary nutrients uptake by soybean

The data on total uptake of secondary nutrients by soybean was found to be significant due to application of different rates of biochar application. Significantly higher total uptake of calcium (34.74 $\left.\mathrm{kg} \mathrm{ha}^{-1}\right)$, Magnesium (18.56 kg ha $\mathrm{kg}^{-1}$ and Sulphur (20.91 kg ha-1) was noticed in $\mathrm{T}_{9}$ which received Recommended NPK + Biochar @ 10 $\mathrm{t} \mathrm{ha}^{-1}+50 \%$ Lime Recommendation when compared to treatment T2 $\left(25.70 \mathrm{~kg} \mathrm{ha}^{-1}\right.$ Calcium, $13.25 \mathrm{~kg} \mathrm{ha}^{-1}$ Magnesium and 17.18 $\mathrm{kg} \mathrm{ha}^{-1}$ Sulphur) which received Package of practice (Recommended NPK + FYM).

Increase in calcium uptake might be due to higher biomass production. Similarly, this might also be due to application of biochar in combination with agricultural lime which contains high amount of calcium which helped in increasing the calcium uptake in soybean. These results are in accordance with Dagnija et al., (2018) and Deluca et al., 2009. Increase in uptake of magnesium might be due to higher biomass production. Similarly, this might also be due to application of biochar which contains high amount of magnesium which helped in increasing the magnesium uptake. Increase in $\mathrm{pH}$ of acidic soil may decrease Al activity, hence better root growth and nutrient uptake can be expected. Nutrient uptake is a function of nutrient content and biomass production. Increased rate of application of biochar, increased biomass production which obviously increased the nutrient uptake. These results are in accordance with Dagnija et al., (2018) and Xu et al., (2014).The uptake of sulphur by soybean was higher in the treatment $\left(\mathrm{T}_{9}\right)$ received Recommended NPK + Biochar @ $10 \quad \mathrm{t} \quad \mathrm{ha}^{-1}+\quad 50 \% \quad$ Lime Recommendation. Increase in $\mathrm{pH}$ of acidic soil may decrease Al activity, hence better root growth and nutrient uptake can be expected. Nutrient uptake is a function of nutrient content and biomass production. Increased rate of application of biochar increased biomass production which obviously increased the nutrient uptake. 
These results are in accordance with Dagnija et al., (2018) and Xu et al., (2014).

\section{Effect of coconut shell biochar on micronutrients uptake by soybean}

Total micronutrients consumption across soybean was substantially different due to various biochar rates (Table 4). Significantly higher total uptake of $\operatorname{Iron}\left(262.07 \mathrm{~g} \mathrm{ha}^{-1}\right)$, Zinc (138.11 $\left.\mathrm{g} \mathrm{ha}^{-1}\right)$, Manganese (106.82 $\left.\mathrm{g} \mathrm{ha}^{-1}\right)$ and copper $\left(31.47 \mathrm{~g} \mathrm{ha}^{-1}\right)$ was observed in T9 which received Recommended NPK + Biochar @ 10 t ha $^{-1}+\quad 50 \% \quad$ Lime Recommendation followed by T5 $(255.93 \mathrm{~g}$ ha $^{-1}$ Iron, $133.65 \mathrm{~g} \mathrm{ha}^{-1}$ Zinc, $103.65 \mathrm{~g} \mathrm{ha}^{-1}$ Manganese and $29.69 \mathrm{~g} \mathrm{ha}^{-1}$ Copper) which received Recommended NPK + Biochar @ 10 $\mathrm{t} \mathrm{ha}^{-1}$. The lower uptake was recorded in absolute control which received no external source of nutrients and biochar as amendment.

The total uptake of micronutrients viz., Fe, $\mathrm{Mn}, \mathrm{Zn}$ and $\mathrm{Cu}$ by soybean varied significantly due to biochar application. Higher total uptake of $\mathrm{Fe}, \mathrm{Mn}, \mathrm{Zn}$ and $\mathrm{Cu}$ by soybean was recorded in the treatment $\left(\mathrm{T}_{9}\right)$ which received Recommended NPK + Biochar @ 10 t ha $^{-1}+\quad 50 \% \quad$ Lime Recommendation and the lower uptake of these micro nutrients was recorded in absolute control where no external source of nutrients and biochar was applied.

Higher uptake of these micronutrients was due to higher biomass production which was recorded due to higher doses of biochar application. Application of biochar is accompanied by increase in soil $\mathrm{pH}$ and reduced mobility of micronutrients. But in presence of plant, which actively releases organic compounds in rhizosphere may mobilize the micronutrients. Lehmann et al., (2003) noticed higher uptake of $\mathrm{Zn}$ and $\mathrm{Cu}$ by the plants with increased levels of biochar due to reduced leaching losses and increased fertilizer use efficiency. Similar findings were also reported by Antonio et al., (2013) and Willis et al., (2016).

In conclusion this study, the biochar was a byproducts of coconut shell using pyrolysis in an oxygen limited condition unlike previously published studies. The characteristics and reactivity of biochars with soil are highly heterogeneous with batches of production using similar feedstock and pyrolytic conditions and the findings of a study could not be applied universally to all biochar materials. In conclusion, this field study demonstrated the effectiveness of biochars in improving soybean yield, nutrients concentrations and uptake of major and micro nutrients. Coconut shell biochar in combination with lime was found to have significantly better performance than coconut shell biochar alone application.

The improvement in yield of soybean may be attributed to improvement in soil physical and chemical properties and availability and controlled release of major and micro nutrients as demanded by soybean by coconut shell biochar. This also attributes to higher nutrient concentration and also the nutrient uptake. This type of studies at different locations with different feed stocks and pyrolytic process will help to design biochar materials as organic amendments for farmers to reclaim acidic soils and improve soil physical, chemical and biological properties.

\section{Acknowledgement}

This field study was supported by AICRP on sunflower unit, ZARS, UAS, GKVK Bangalore, Karnataka, Department of soil science and agricultural chemistry, UAS, GKVK, Bangalore and KVK, Tiptur, Tumkur district, Karnataka. 


\section{References}

Antonia, J. A., Pablo, S., Vidal, B., Jose, T., Maria-del, C. C., Antonia, G. and Rafael, V., 2013, Enhanced wheat yield by biochar addition under different mineral fertilization levels. Agron. sustain. Dev., 33: 475-484.

Aziz, R., Muhammad, N., Brookes, P. C. and $\mathrm{Xu}, \mathrm{J} ., 2017$. Impact of wheat straw bio char on yield of rice and some properties of Psammaquent and Plinthudult. $J$. Soil Sci. Plant Nut., 17(3): 808-823.

Beesley, L. and Marmiroli, M., 2011, The immobilisation and retention of soluble arsenic, copper, cadmium and zinc by biochar. Environ. Pollut., 159: 474 480.

Chamorro, A. M., Tamagno, L. N., Bezus, R. and Sarandon, S. J., 2002, Nitrogen accumulation partition and nitrogen use efficiency in canola under different nitrogen availabilities. Soil Sci. Pl. Anal., 33: 493-504.

Chan, K. Y., Van Zwieten, L., Meszaros, I., Downie, A. and Joseph, S., 2007, Agronomic values of green waste biochar as a soil amendment. J. SoilRes., 45: 629-634.

Dagnija, V., Lelde G, L., Galina, M., Raimonds, K., Turs, S., Vilhelmine, S., Solvita, S., Christoph, S. and Olga, M., 2018, The impact of wood-derived biochar on the survival of Trichoderma spp. and growth of Secalecereale L. in sandy soil. Biocontrol Sci. tech., 28(4): 341-358.

Deluca, T. H., Mackenzie, M. D. and, M. J., 2009, Biochar effects on soil nutrient transformations. Earth. scan., 5: 72-87.

Eazhilkrishna, N., Thilagavathi, T. and Baskar, M., 2017, Eco friendly utilization of nutrient enriched biochar from sugar industry wastes and its effect on yield and NPK uptake by hybrid maize grown in vertisol. Int. J. Agric.
Sci. 9(31): 4456-4459.

Gomez, K. A. and Gomez, A. A., 1984, Statistical Procedures for Agric. Res. $2^{\text {nd }}$ Ed. John Wiley \& Sons, New York.

Glaser, B., Balashov, E., Haumaier, L., Guggenberger, G. and Zech, W., 2000, Black carbon in density fractions of anthropogenic soils of the Brazilian Amazon region. Org. Geochem., 31: 669-678.

Jackson, M.L., 1973, Soil chemical analysis. Prentice Hall of India, New Delhi, 1: 485-486

Lehmann, J. D., Silva J. R., J. P., Steiner, C., Nehls, T., Zech, W. and Glaser, B., 2003, Nutrient availability and leaching in an archaeological Anthrosol and a Ferralsol of the Central Amazon basin: fertilizer, manure and charcoal amendments. Pl. Soil., 249: 343-357.

Lehmann and Joseph., 2009, An investigation into the reactions of biochar in soil. Soil Research, 48(7): 501-515.

Major, J., Rondon, M., Molina, D., Riha, S. and Lehmann, J., 2010, Maize yield and nutrition during 4 years after biochar application to a Colombian savanna Oxisol. Pl. Soil., 333: 117-128.

Milla, V. O., Rivera, E., Huang, W. J., Chien, C. C. AND WANG, Y. M., 2013, Agronomic properties and characterization of rice husk and wood biochars and their effect on the growth of water spinach in a field test. J. Soil Sci. Plant Nutri., 13(2), pp. 51-266.

Piper, C. S., 1966, Soil and plant analysis, Hans Pub: Bombay,7: 368-369.

Sohi, S., SOLOMON, D., Liang, B., Lehmann, J., Thies, J. E., Skjemstad, J. O., Luizaod, F. J., Engelharde, M. H., Nevesf, E. G. and Wirick, S. 2009, Stability of biomass derived black carbon in Soils. Sci. Rep., 72: 60696078.

Uzoma, XU, G., Wei, L. L., Sun, J. N., Shao, H. B. and Chang, S. X., 2011, What is 
more important for enhancing nutrient bioavailability with biochar application into a sandy soil: Direct or indirect mechanism. Ecol. Eng., 52: 119-124.

Van Zwieten, L., Kimber, S., Downie, A., Morri, S., Petty, S., Rust, J. and chan, K.Y., 2010, A glass house study on the interaction of low mineral ash biochar with nitrogen in a sandy soil. Aust. $J$. Soil Res., 48: 569-576.

Wang, S., Zhao, X., Xing, G. and Yang, L.,
2013. Large-scale biochar production from crop residue: A new idea and the biogas-energy pyrolysis system. J. Bio. Res., 8(1): 8-11.

Xu, G., Wei, L. L., Sun, J. N., Shao, H. B. and Chang, S. X., 2014, What is more important for enhancing nutrient bioavailability with biochar application into a sandy soil: Direct or indirect mechanism. Ecol. Eng., 52: 119-124.

\section{How to cite this article:}

Rohitha, D. S., B. Mamatha, K. M. Srinivas Reddy, H. C. Prakasha and Nagappa Desai. 2020. Influence of Different Levels of Coconut Shell Biochar on Nutrients Concentration and Nutrient Uptake by Soybean. Int.J.Curr.Microbiol.App.Sci. 9(12): 456-467.

doi: https://doi.org/10.20546/ijcmas.2020.912.056 